\title{
Satisfaction with Working Time before the Covid-19 Pandemic in European Societies: Results of Multilevel Analysis
}

Satisfaction with working time gains increasing importance in the context of changing sphere of work, spread-out of flexible forms of employment, digitalisation and telework in the recent times of the COVID-19 pandemic. The paper focuses on the factors associated with satisfaction with working time in European countries before the pandemic based on data from the European Quality of Life Survey (2016). The study serves as a basis for further comparison of the trend in working time satisfaction in the pre-pandemic period across Europe and the recent period of increasing flexibilisation of work, digitalisation and spread-out of distant employment. For this purpose, descriptive statistical analyses and two-level random intercept model for binary responses are applied. The results show that women report higher satisfaction with working time compared to men. Satisfaction significantly increases after the age of 40. The number of children and the presence of children below the age of 6 in the household are negatively associated with satisfaction with working time. Satisfaction is positively associated with income and education. Structural conditions, such as economic development measured by gross domestic product (GDP), influence Europeans' working time satisfaction. In the Balkan countries, satisfaction with working time is the lowest, while in the North-Western societies the highest percentage of workers are satisfied with working time before the COVID-19 pandemic.

Keywords: satisfaction with working time, work-life balance, socio-economic development, European Quality of Life Survey, multilevel analysis

For citation: Dimitrova, E. K. (2021). Satisfaction with Working Time before the COVID-19 Pandemic in European Societies: Results of Multilevel Analysis. Ekonomika regiona [Economy of regions], 17(4), 1210-1223, https://doi.org/10.17059/ ekon.reg.2021-4-12

\footnotetext{
1 c Dimitrova E. K. Text. 2021.
} 


\section{Э. К. Димитрова}

Институт народонаселения и гуманитарных исследований Болгарской академии наук, София, Болгария https://orcid.org/0000-0002-5697-220X,e-mail: elitsa_kdimitrova@yahoo.com

\section{Удовлетворенность продолжительностью рабочего дня до пандемии Covid-19 в странах Европы: результаты многоуровневого анализа}

Фактор удовлетворенности продолжительностью рабочего дня играет важную роль в контексте трансформации сферы трудовых отношений, распространения гибких и удаленных форм занятости, перехода на цифровые технологии в период пандемии COVID-19. На основе данных Европейского исследования качества жизни за 2016 г. в статье были проанализированы факторы удовлетворенности продолжительностью рабочего дня в странах Европы до начала пандемии. Проведенный анализ позволяет сравнить тенденции удовлетворенности продолжительностью рабочего дня, наблюдаемые в Европе до и во время пандемии (учитывая повышение гибкости рабочего графика, цифровизацию и распространение удаленных форм занятости). Для этой цели были применены метод описательной статистики и двухуровневая модель случайных перехватов двоичных ответов. Результаты показывают, что женщины более удовлетворены своим рабочим графиком, чем мужчины. Удовлетворенность значительно возрастает после 40 лет. Такие факторы, как количество детей и наличие детей в возрасте до 6 лет отрицательно влияют на удовлетворенность продолжительностью рабочего дня. В то же время удовлетворенность положительно связана с уровнем дохода и образования. Структурные условия, например, показатель экономического развития, измеряемый с помощью валового внутреннего продукта (ВВП), также влияют на удовлетворенность европейцев работой. В балканских странах уровень удовлетворенности продолжительностью рабочего дня самый низкий, в то время как в северо-западных странах Европы до пандемии COVID-19 был зафиксирован самый высокий процент работников, удовлетворенных графиком работы.

Ключевые слова: удовлетворенность продолжительностью рабочего дня, баланс между работой и личной жизнью, социально-экономическое развитие, Европейское исследование качества жизни, многоуровневый анализ

Для цитирования: Димитрова Э. К. Удовлетворенность продолжительностью рабочего дня до пандемии COVID-19 в странах Европы: результаты многоуровневого анализа // Экономика региона. 2021. Т. 17, вып. 4. С. 1210-1223. https:// doi.org/10.17059/ekon.reg.2021-4-12.

\section{Introduction}

Working time satisfaction gains increasing importance in the recent context of changing sphere of work, work life balance, spread-out of flexible forms of employment, digitalisation and telework, which were accelerated by the socio-economic implications of the Covid-19 pandemic. Research shows that flexibilisation and digitalisation are associated with higher autonomy at work but also with increased working hours, higher job-related stress and reduced time for interaction with family $[1,2]$. Studies show that work-life balance becomes an important dimension of well-being for the generation $\mathrm{X}$ individuals born between the 1960s and 1980s [3]. According to the role theory, the individual fulfils different roles in the sphere of paid work and private life [4]. Role balance depends on the degree of engagement in the different roles. Role conflict emerges when an individual cannot meet certain role expectations, e.g. when workload and working hours impede the fulfilment of family responsibilities. Role conflicts are associated with higher stress and decreased engagement at work and family duties due to unfulfilled and conflicting role expectations. While long working hours can influence family life, the overwhelming family duties may also impede the fulfilment of job tasks. Research shows that the dominant transfer influencing work-life balance is that from work to private life [6, 7]. According to Greenhaus and Allen [8], life-work balance reflects an absence of conflict between the two spheres. Carlson, Grzywacz and Zivnuska [9] claim that life-work balance exceeds the absence of conflict between paid work and private life since the two spheres are mutually inclusive. Greenhaus and Powell [10] use the term 'work-family enrichment' instead of life-work balance. Marks and MacDermid [11] emphasise the importance of satisfaction with the role fulfilment, claiming that work-life balance is achieved when the role engagement corresponds with personal preferences.

Wagner ${ }^{1}$ considers working hours and working time arrangements as central elements of

\footnotetext{
${ }^{1}$ Wagner, S. (2017). What makes employees satisfied with their working time? The role of working hours, time-sovereignty and working conditions for working time and job satisfaction. IAB - Discussion Paper, 20/2017. Retrieved from:
} 
work conditions that influence the possibilities for employees to achieve work-life balance. He also demonstrates that workers' time autonomy increases working time satisfaction, as worker-friendly time arrangements decrease work-related stress, while atypical work hours such as overtime and work on shifts reduce employees' satisfaction. Shagvaliyeva and Yazdanifard [13] show that flexible working hours are associated with reduced work-related stress. Holly and Mohnen ${ }^{1}$ reveal that the desire to reduce working hours negatively affects job and life satisfaction. The results from a study conducted by Anttila et al. [12] reveal that the flexibility of working time predicts perceived work-life balance in European countries. According to Anttila et al. [12], the industrial working time model features an 8-hour work day, a 5-day work week during the day, free weekends and annual holidays. The authors claim that the temporal and spatial flexibilisation of work in the post-industrial regime is characterised by "deregulation of collective norms, diversification of the length (short and long hours) and pattern of working time (unsocial hours), increasing work intensity and time squeeze, and blurring of the limits of working and leisure time". According to the same study [12], the new "working-time mosaic" is associated with increased autonomy of the employees but it also may have negative influence by transgression of the borders between work and family life.

Studies on working time preferences and their 'match' and 'mismatch' with the working time reveal that individuals' preference are often ambivalent. According to Campbell and van Wanrooy [14], employees hold multiple, often conflicting ideas about working time and, in particular, about the feasibility of reduced working hours. Tijdens [15] reveals that the individual preferences on working time depend on different social status characteristics of workers. The study shows that breadwinning and part-time employees are in favour of the reduction of working time due to the negative impact it could have on income as well as the increase of non-working hours is more valued by women, particularly those with small children [15]. Humbert ${ }^{2}$ also found gender-specific differences

http://213.241.152.197/discussionpapers/2017/dp2017.pdf (Date of access: 03.12. 2021).

1 Holly, S. \& Mohnen, A. (2012). Impact of working hours on work-life balance. SOEP papers on Multidisciplinary Panel Data Research, No. 465, Deutsches Institut für Wirtschaftsforschung (DIW), Berlin. Retrieved from: www.diw.de > diw_01.c.407372. de > diw_sp0465 (Date of access: 03.12.2021).

2 Humpert, St. (2014), Working time, satisfaction and work life balance: A European perspective. Working Paper No 327, in working time mismatch, showing that for men life and job satisfaction are not associated with working more or less hours. However, the same study shows that women are more sensitive to the amount of working hours; they more often prefer part-time jobs as well as show higher dissatisfied with over-time and under-time work compared to men. Over the past decades, the progressive standardisation of working time was challenged by the diversification and individualisation of work time arrangements as a result of digitalisation and increased use of information and communication technology (ICT). These trends provoke debates about working time reduction and flexibilisation of working hours in the post-industrial societies [16]. Possenriede and Plantenga ${ }^{3}$ reveal that the access to flexible work arrangements, especially flexi-time, is associated with an increase in overall job satisfaction and working time fit.

\section{Data and Methods}

The purpose of the present study is to outline the factors associated with working time satisfaction as a component of life-work balance of the European citizens. Data from the "European Quality of Life Surveys" ${ }^{4}$ of Eurofound was used in the analysis. European Quality of Life Survey (EQLS) aims to explore the conditions of live and work of the EU citizens. The survey is conducted every 4 years since 2003 and the topics are related to employment, income, life-work balance, subjective well-being, life satisfaction and quality of life ${ }^{5}$. EQLS-2016 was conducted in 33 countries. The number of individuals who responded to the question how well the time for paid work combines with the time for family duties or other social engagements is 17963 . The design of the survey allows for the application of multilevel analysis in order to explore the factors associated with working time satisfaction at the individual and

Series in Economics, University of Lüneburg, Institute of Economics. Retrieved from: https://EconPapers.repec.org/ RePEc:lue:wpaper:327. (Date of access: 03.12.2021).

3 Possenriede, D. \& Plantenga, J. (2011). Access to flexible work arrangements, working-time fit and job satisfaction. Utrecht School of Economics Tjalling C. Koopmans Research Institute. Discussion Paper Series 11-22. Retrieved from: https://www.uu.nl/files/rebousedp201111-22pdf (Date of access: 03.12.2021).

${ }^{4}$ Information about EQLS can be found on the following website: https://www.eurofound.europa.eu/surveys/european-quality-of-life-surveys (Date of access: 03.12.2021).

Eurofound (2018). Striking a Balance: Reconciling Work and Life in the EU. Publications Office of the European Union, Luxembourg. https://www.eurofound.europa.eu/publications/ report/2018/striking-a-balance-reconciling-work-and-life-inthe-eu (Date of access: 03.12.2021). 
country levels. The individual level factors include gender, age, marital status, number of children, presence of child below the age of 6 years in the household, self-rated health, education, income and labour status of the respondent ${ }^{1}$. Additionally, the influence of the socio-economic context of the countries participating in the survey, measured by gross domestic product (GDP) per capita based on purchasing power parity is included in the multilevel model ${ }^{2}$. Studies conducted by OECD reveal that GDP is correlated with the indicators of life-work balance at the macro level ${ }^{3}$. The multilevel model that is applied is random intercept model for binary response data, which accounts for the variation between the countries in the levels of satisfaction with the time for paid work. The model reflects the hypothesis that satisfaction with working time depends both on the individual characteristics as well as on the socio-economic context of a particular country. The results of the analysis, which reflect the situation before the Covid-19 pandemic, can serve as a basis for comparison of the trends in working time satisfaction in the pre-pandemic period and the recent trends of increasing flexibilisation, digitalisation and spread-out of distant employment due to the socio-economic implications of the pandemic. The coming waves of the survey allow for the comparison and deeper understanding of these changes in future research.

\section{Study Results}

In EQLS, the match and mismatch between working time and time for family and social life is measured by the question: "In general, how do your working hours fit in with your family or social commitments outside work?". Overall, the data reveal high level of satisfaction with working time among Europeans [17]. Figure 1 shows that for

\footnotetext{
${ }^{1}$ An early version of the analysis can be found in the following conference paper: Dimitrova, E. K. (2019). Social Differences in the Attitudes Towards the Balance of Time for Paid Work and Private Life in European Perspective. In: Sotsialnoekonomicheskie i demograficheskie aspekty realizatsii natsionalnykh proektov $\mathrm{v}$ regione: sbornik statey X Uralskogo demograficheskogo foruma. Tom I [Socio-economic and demographic aspects of the implementation of national projects in the region: a collection of articles of the X Ural Demographic Forum. Volume 1] (pp. 118-124). Ekaterinburg: Institute of Economics UB RAS.

${ }^{2}$ Data of GDP per capita based on purchasing power are downloaded from the online database of the World Bank https://data. worldbank.org/ (Date of access: 03.12.2021).

3 Information on the index of life-work balance trends in OECD countries can be found on the following website http:// www.oecdbetterlifeindex.org/topics/work-life-balance/ (Date of access: 03.12.2021).
}

the majority of respondents (77.2\%), the time for paid work fits in very or rather well with their family or social engagements. Only $4.1 \%$ of the surveyed people experience problems with combining working time and family life.

Analysis by gender shows that women report slightly more often that they are satisfied with their working time compared to men $(78.5 \%$ and $76.1 \%$ ) (Figure 2). Difficulties to combine working time with private responsibilities experience only 4-5\% of men and women.

Younger respondents who are in the most active part of their lives, when they form their own families and raise children, more frequently experience difficulties in the reconciliation of time for paid work and family responsibilities (Figure 3) [17]. $24.4 \%$ of the respondents at age $18-24$ years report that it is very easy to combine working time and family duties, while among the older respondents at age 50-64 years and among those above $65+$ years, $27.9 \%$ and $41.9 \%$ positively evaluate their working time.

Respondents who do not have a partner most often claim that their working time combines very well with other family or social commitments: $27.3 \%$ of the never married, $30.1 \%$ of widowed and $26.8 \%$ of the divorced respondents feel satisfied with their working time (Figure 4). Slightly above $50 \%$ of the individuals in all categories state that their working time fits in rather well with other private engagements. Almost one fourth of the participants negatively assess the way working time combines with family or social commitments. The divorced and separated respondents most frequently report that working time does not fit in well at all with other private duties (5-6\%).

The respondents without children most often report that their working time fits in (very) well with other family or social engagements $-79.8 \%$ (Figure 5). The percentage of those who negatively evaluate the reconciliation of their working time and family commitments is highest among individuals with three or more children $-6.2 \%$.

The respondents with tertiary education most often report that their working time combines very well with private duties $(27.5 \%)$, while the low education individuals experience more difficulties (Figure 6). Among the respondents with lower secondary education or below, the percentage of those who state that their working time and private life combine not well at all is the lowest (3.6\%).

There is a significant difference in the working time satisfaction by employment status of the respondents (Figure 7). Among the retired people who are still employed, the percentage of those 


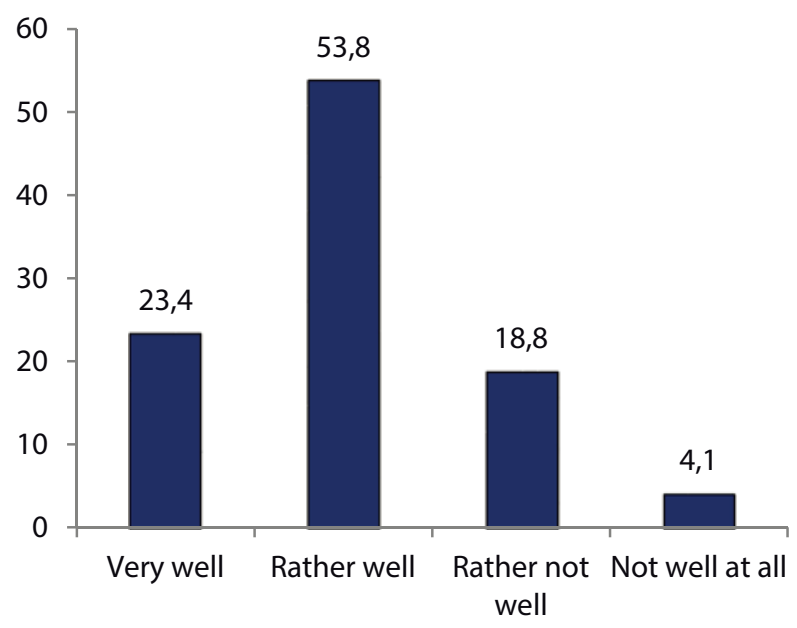

Fig. 1. "In general, how do your working hours fit in with your family or social commitments outside work?" (\%)

Source: European Quality of Life Survey 2016, Eurofound, author's estimates

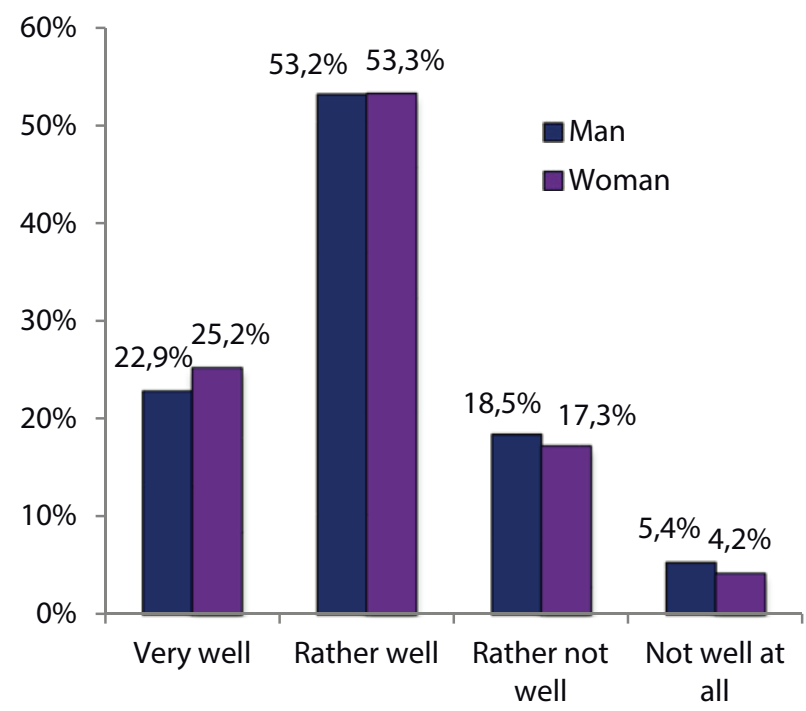

Fig. 2. "In general, how do your working hours fit in with your family or social commitments outside work?" by gender (\%) Source: European Quality of Life Survey 2016, Eurofound, author's estimates who state that their working time combines very well with the time for family or other social commitments is the highest (42.4\%). Unlike them, the employees who are on childcare leave, i.e. have small children, most frequently negatively evaluate the reconciliation of their working time and family responsibilities (6.8\%).

Figure 8 presents the ranking of the countries participating in EQLS by the percentage of individuals who are very/rather satisfied with their working time and the way it combines with private life. On top positions are Sweden, Denmark and the Netherlands. In these countries, more that $85 \%$ of the respondents report that their working time fits in very well or rather well with private life. The east-west division is also partly present on the graph. Western European countries like Austria, Iceland, Luxembourg, Ireland, Finland, Germany and Belgium have above the average percentage of individuals who are satisfied with working time. Eastern European countries live Slovakia, Lithuania, Estonia, Romania and Poland are also positioned above the average. At the bottom of the ranking are Turkey, Bulgaria, Greece and Serbia. In these countries, 60-67\% of the individuals report that their working time fits in very or rather well with their engagements in private life. Mediterranean countries like Italy, Portugal and Spain are characterised by below average percentage of individuals who are satisfied with the way working time reconciles with private life. Some of the explanations of these results relate to high level of socio-economic development and the advanced process of diversification and individualisation of work arrangements, especially in Western European countries. The Scandinavian countries have well developed welfare regimes and large investments in social protection, including policies of work-life balance. On the other ex-

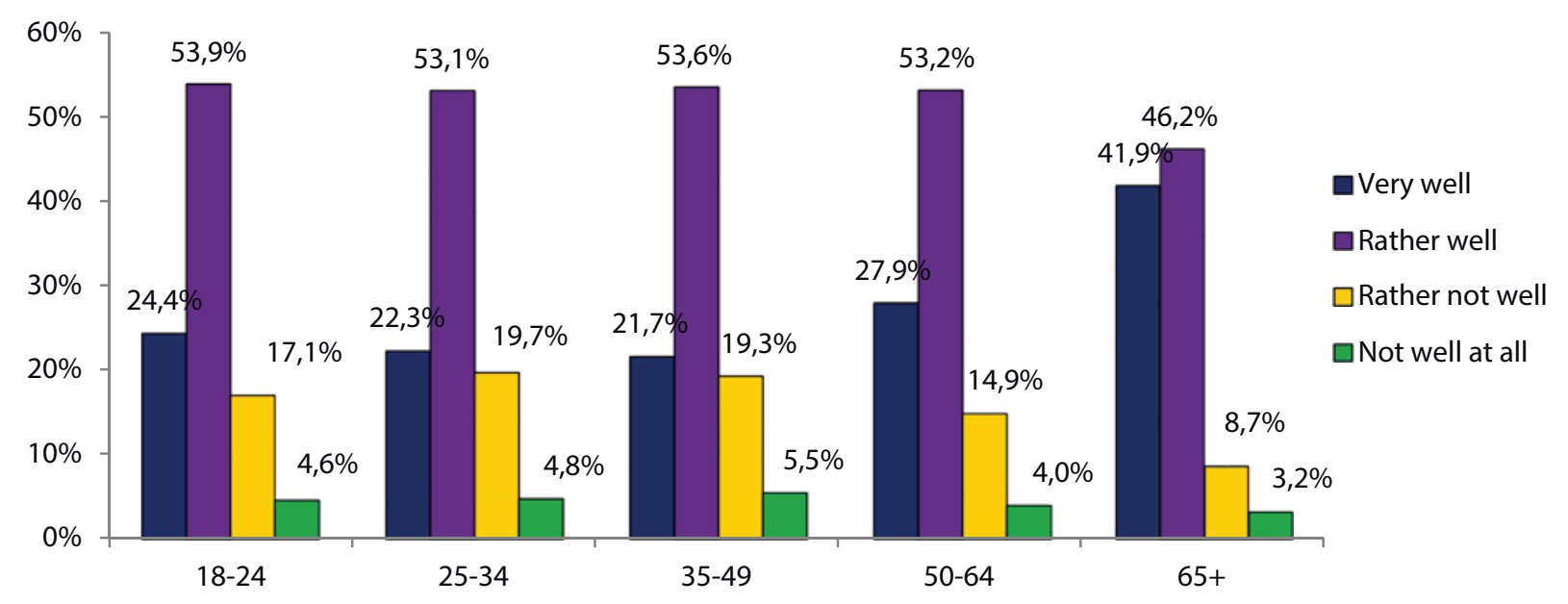

Fig. 3. "In general, how do your working hours fit in with your family or social commitments outside work?" by age (\%) Source: European Quality of Life Survey 2016, Eurofound, author's estimates 


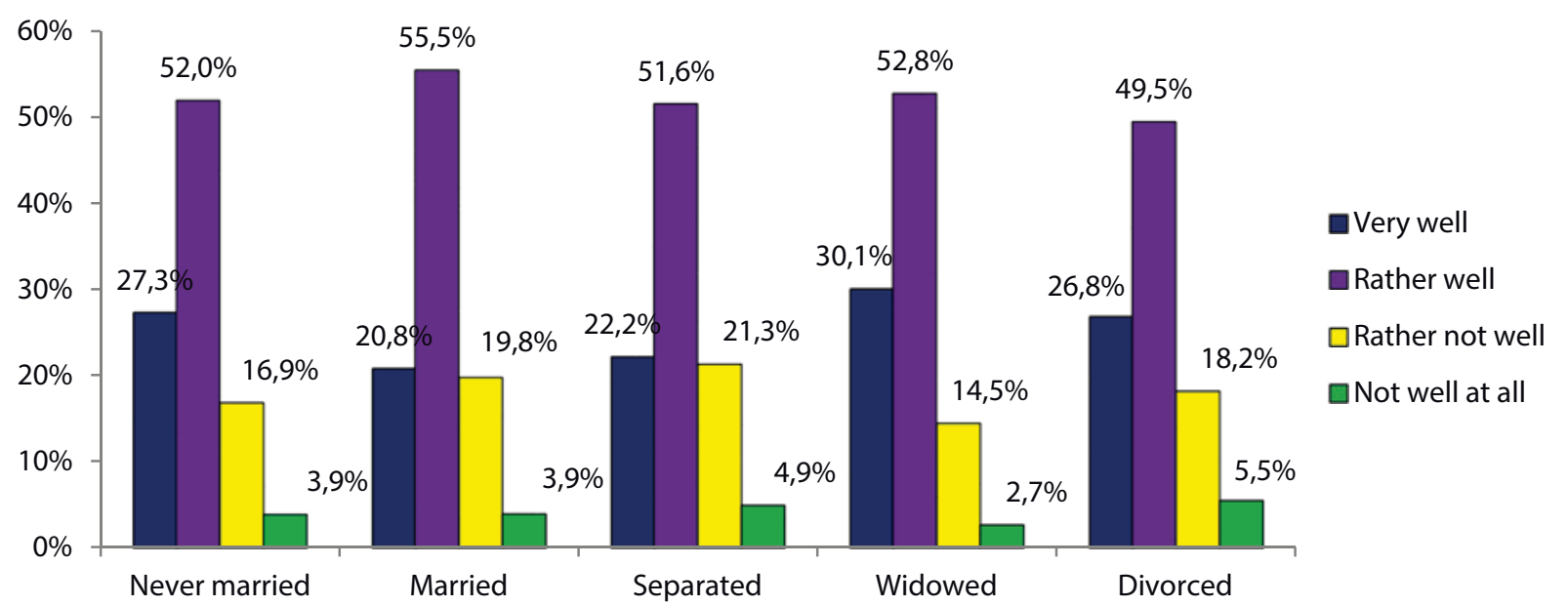

Fig. 4. "In general, how do your working hours fit in with your family or social commitments outside work?" by marital status (\%) Source: European Quality of Life Survey 2016, Eurofound, author's estimates

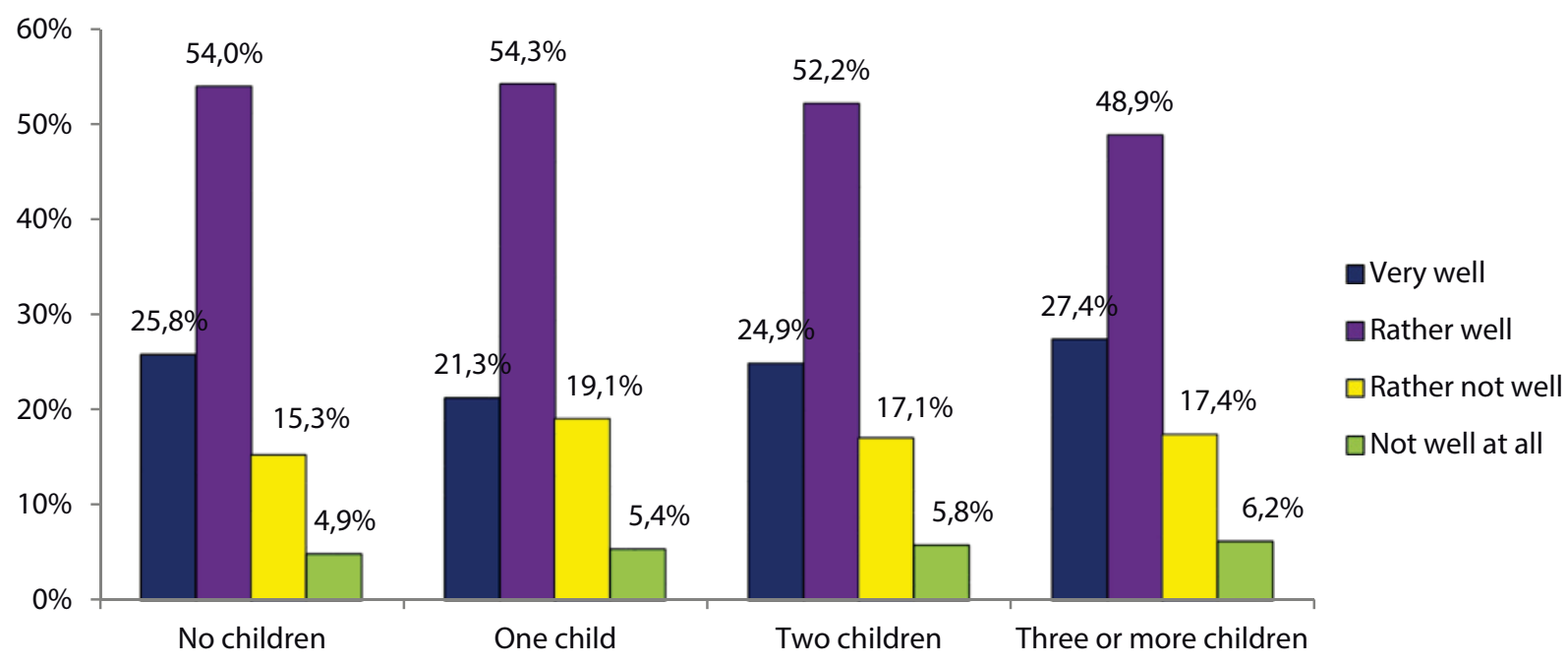

Fig. 5. "In general, how do your working hours fit in with your family or social commitments outside work?" by the number of children (\%)

Source: European Quality of Life Survey 2016, Eurofound, author's estimates

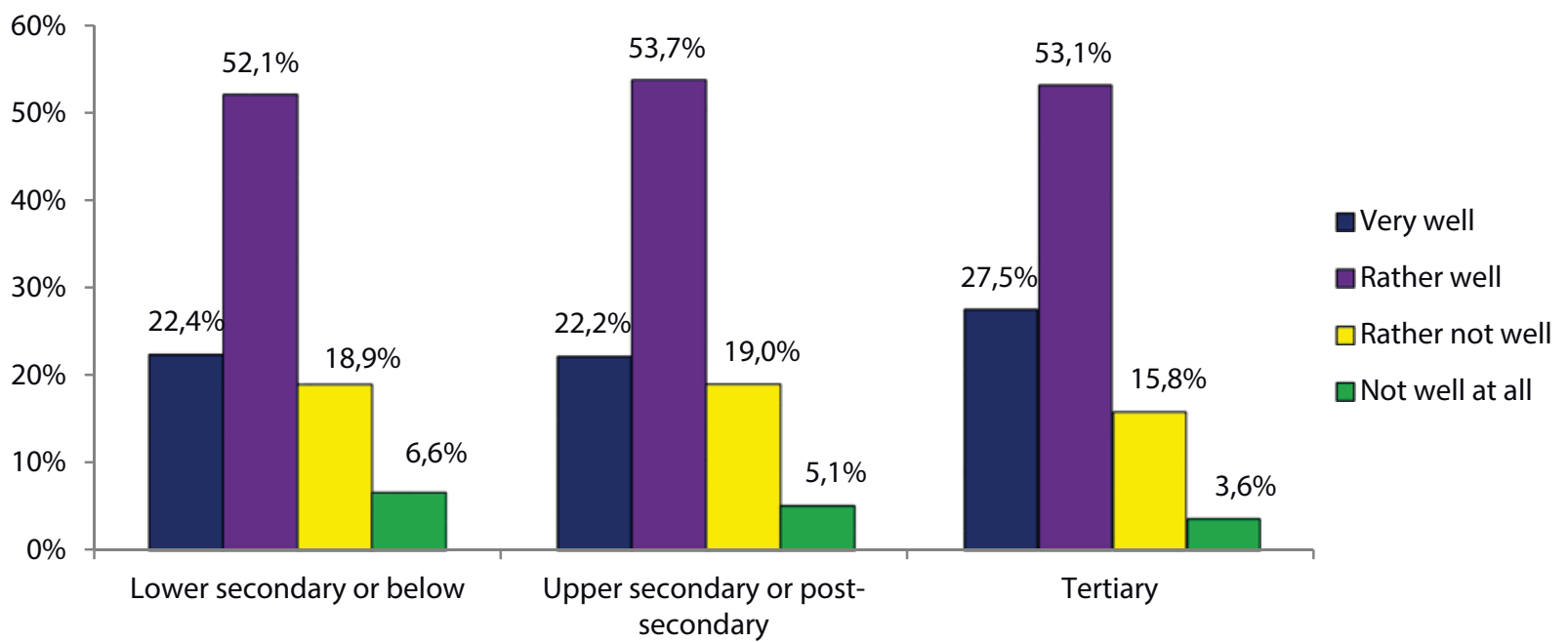

Fig. 6. "In general, how do your working hours fit in with your family or social commitments outside work?" by education (\%) Source: European Quality of Life Survey 2016, Eurofound, author's estimates 


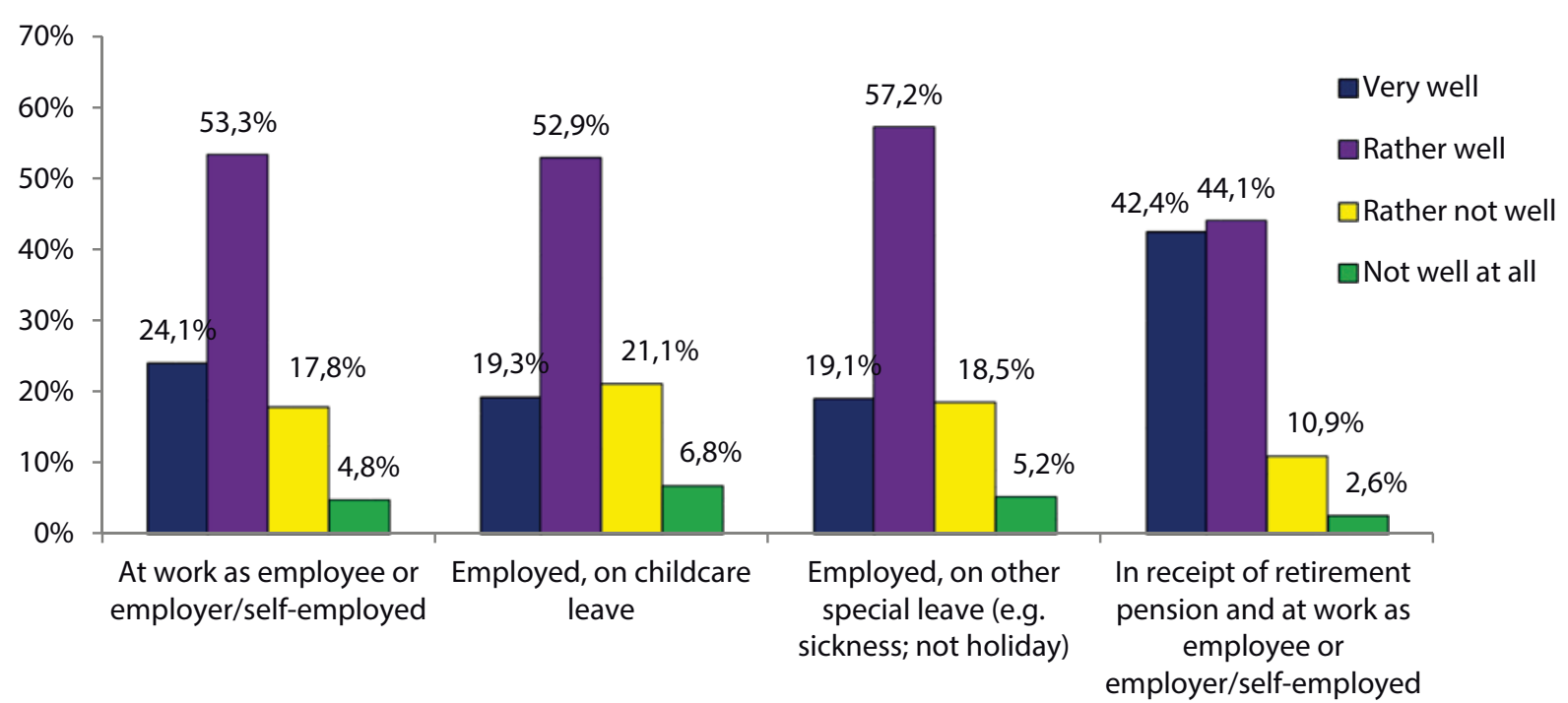

Fig. 7. "In general, how do your working hours fit in with your family or social commitments outside work?" by employment status (\%)

Source: European Quality of Life Survey 2016, Eurofound, author's estimates

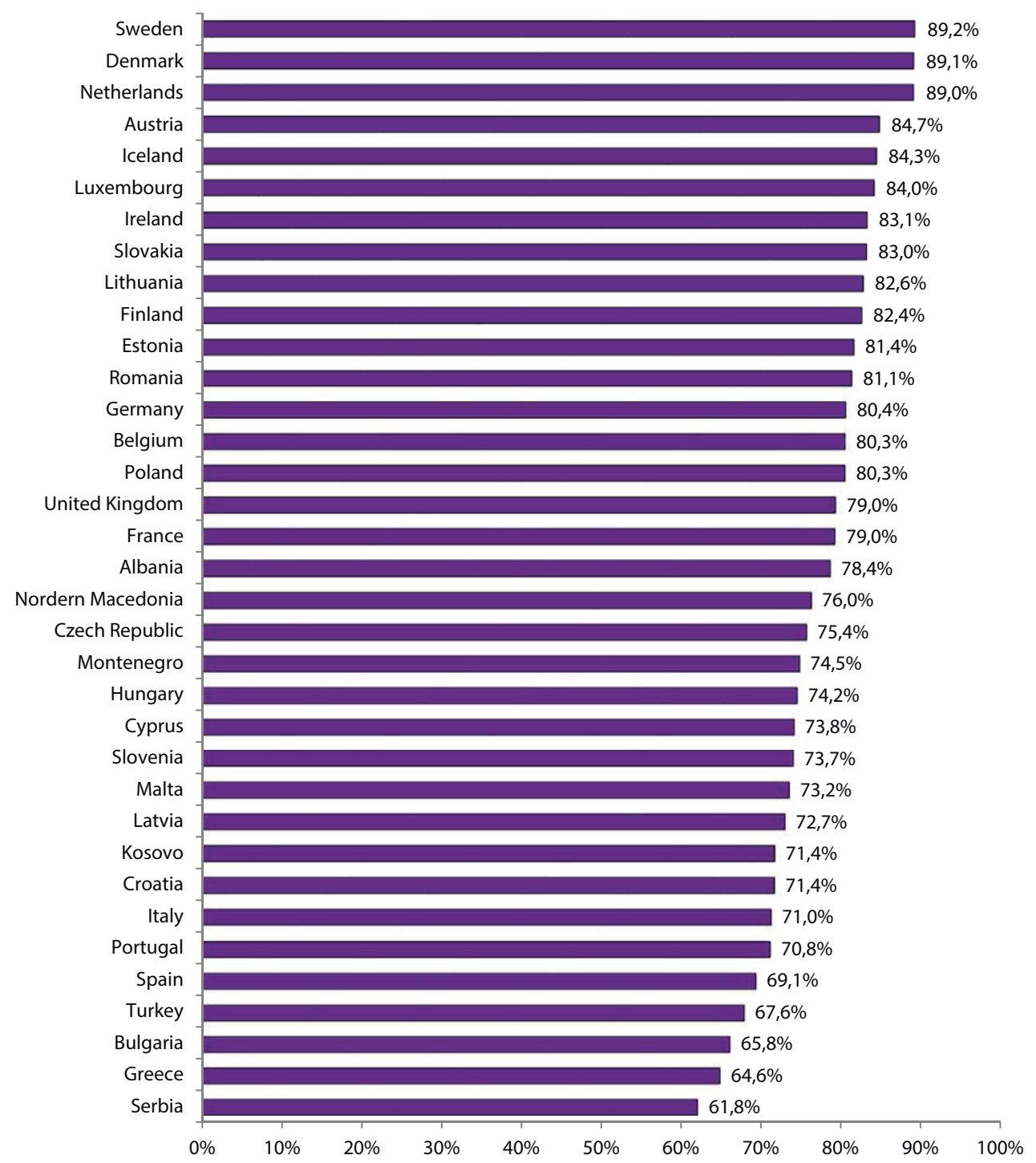

Fig. 8. In general, how do your working hours fit in with your family or social commitments outside work?" by country (responses "very or rather well") (\%)

Source: European Quality of Life Survey 2016, Eurofound, author's estimates 


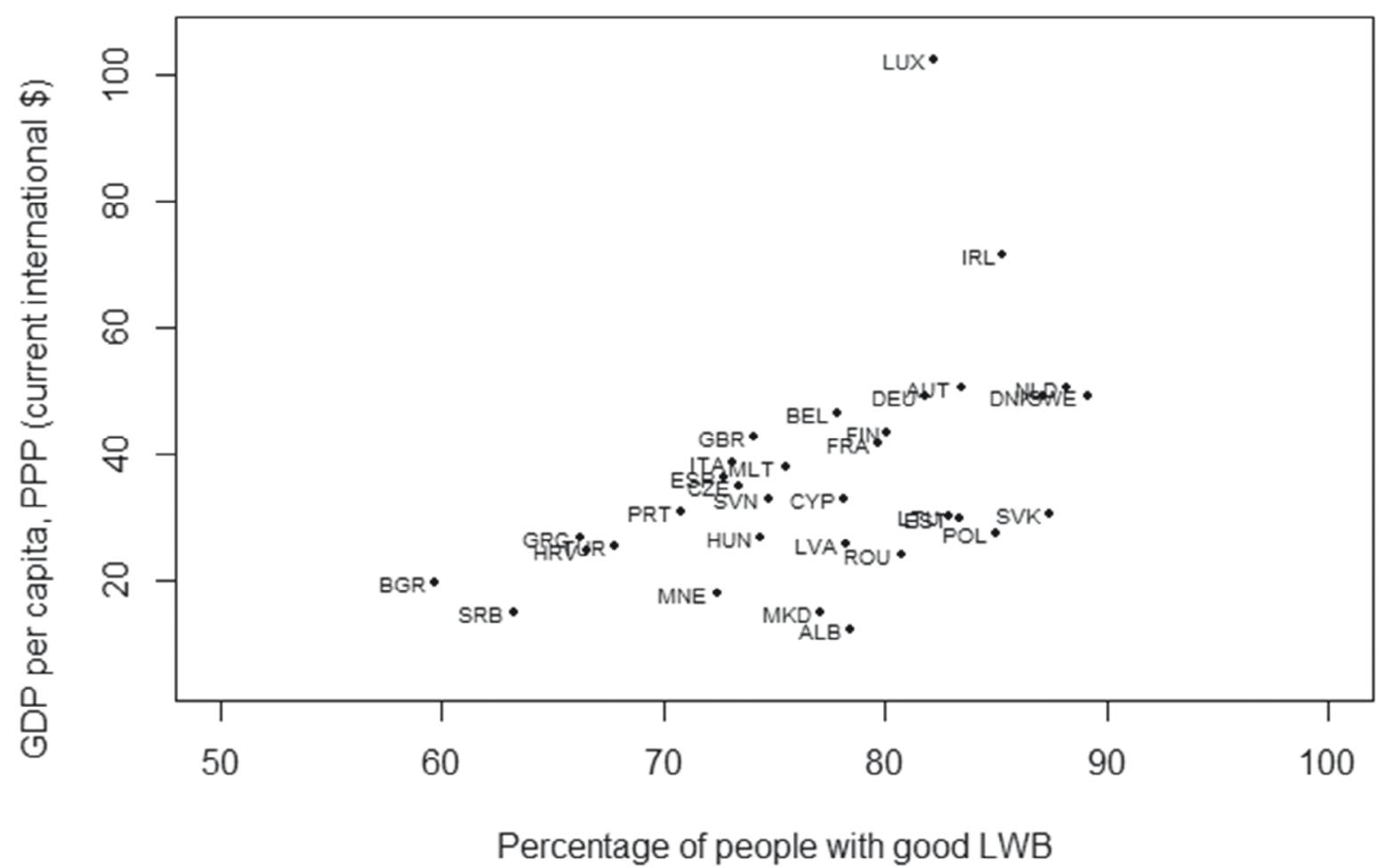

Fig. 9. GDP per capita, PPP (current international \$) and percentage of people having good balance of time between private life and work in the countries participating in EQLS

Source: (1) European Quality of Life Survey 2016, Eurofound, author's estimates.

(2) World bank — online database: https://data.worldbank.org

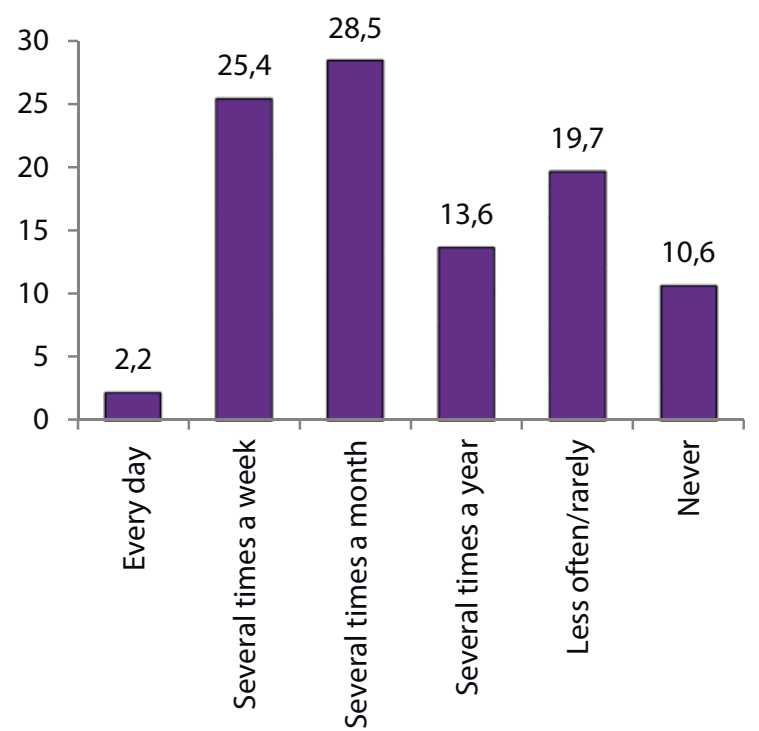

Fig. 10. "I have come home from work too tired to do some of the household jobs which need to be done" (\%)

Source: European Quality of Life Survey 2016, Eurofound, author's estimates

treme are the Balkan countries, which are less advanced in the process of flexibilisation of work arrangements, have lower socioeconomic development and underdeveloped work-life reconciliation policies. These results are in line with the existing analyses, revealing several clusters of European countries with diverging working time regimes:

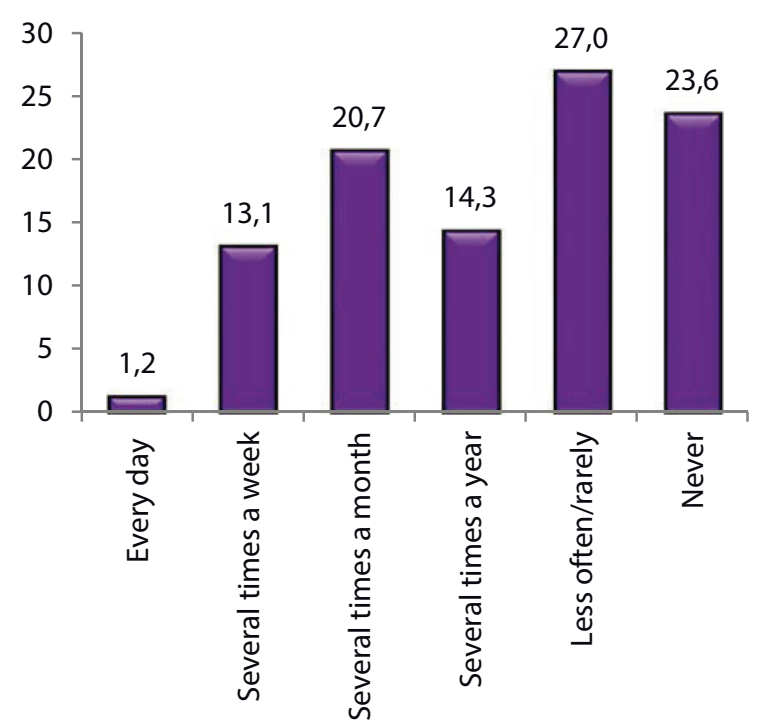

Fig. 11. "It has been difficult for me to fulfil my family responsibilities because of the amount of time I spend on the job" (\%) Source: European Quality of Life Survey 2016, Eurofound, author's estimates

Northern countries (Finland, Sweden, Denmark and Netherlands), Central European countries (Austria, Germany, Belgium, Luxembourg, France), Southern countries (Italy and Spain) with the United Kingdom and Ireland and Eastern European cluster (Czech Republic, Estonia, Slovenia, Greece, and Hungary) [12, p. 718]. 


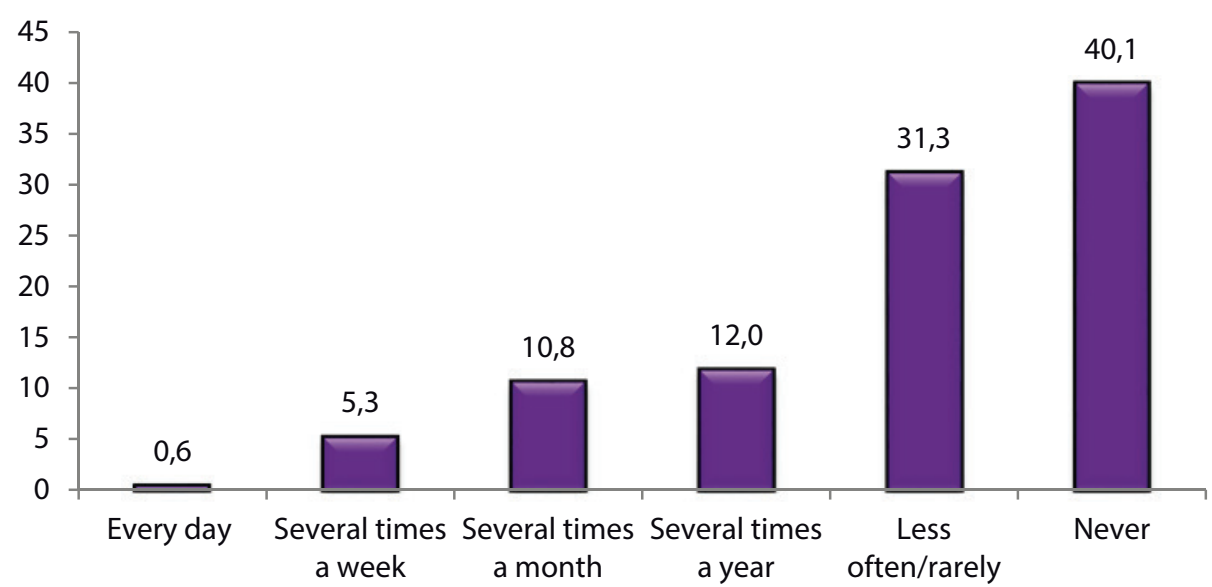

Fig. 12. "I have found it difficult to concentrate at work because of my family responsibilities" (\%) Source: European Quality of Life Survey 2016, Eurofound, author's estimates

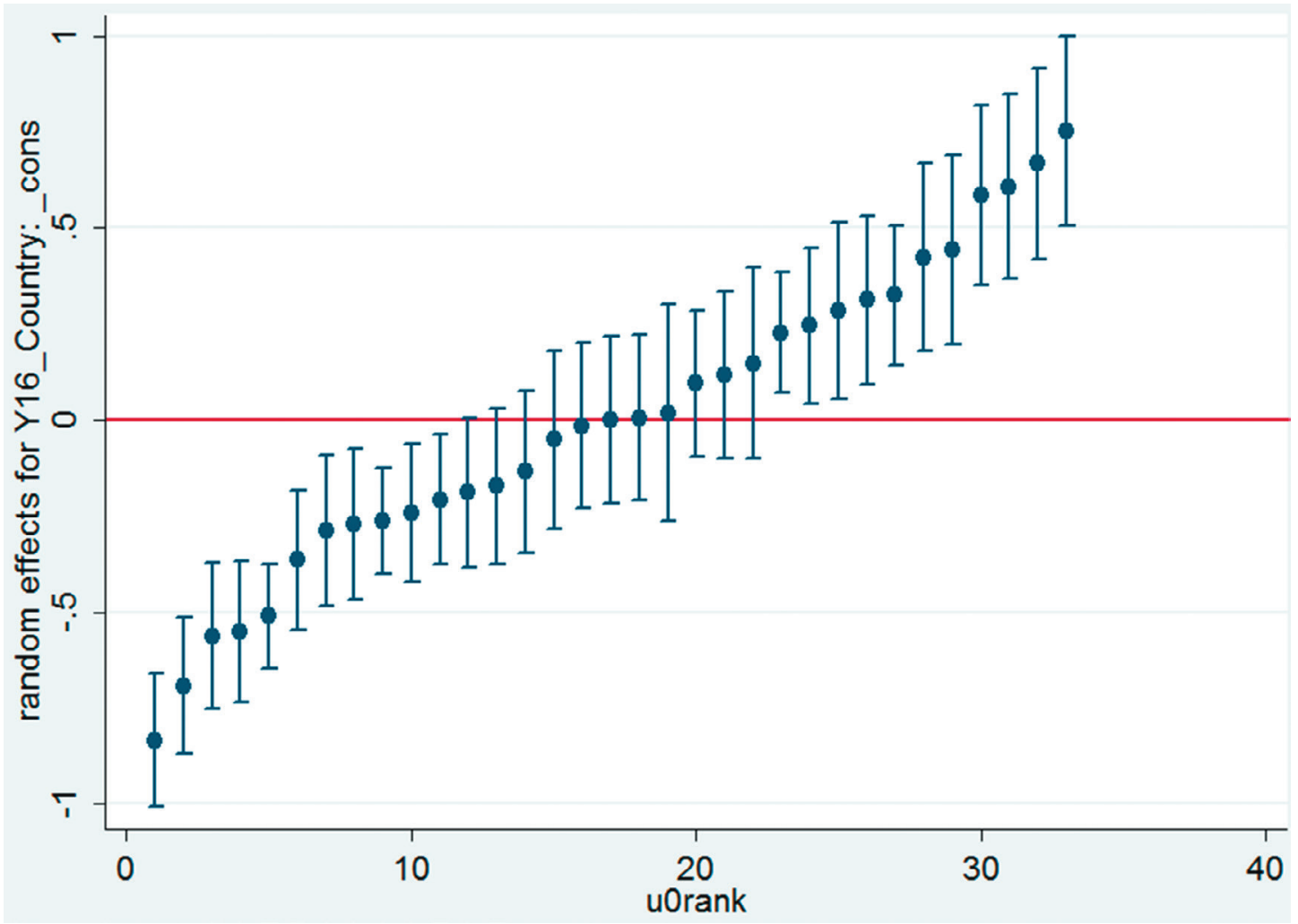

Fig. 13. Caterpillar plot of the variance in satisfaction with working time in European countries Source: European Quality of Life Survey 2016, Eurofound, author's estimates

Figure 9 presents the relationship between satisfaction with working time and the socio-economic development of the countries participating in EQLS. There is a positive correlation between GDP and the share of individuals satisfied with the reconciliation between working time and family or social commitments. The graph shows that Ireland and Luxembourg are characterised by high GDP and very high percentage of people who are satisfied with working time. Bulgaria and Serbia are at the opposite extreme positions due to lower GDP and the lowest percentage of respondents who are satisfied with the balance of time for paid work and private life.
The individual perceptions of reconciliation between working time and family and social engagements depend also on the type of the transfers between work and home [18]. Figure 10 reveals high levels of transfer from work to private sphere. $2.2 \%$ of the respondents state that every day they feel too tired to fulfil their household duties due to overwork. This happens several times a week or several times a month for $54 \% .13 .6 \%$ experience negative transfer from work to home several times a year, while $30.3 \%$ report that they have never had difficulties to do their household duties due to work engagements. 
Figure 11 shows that $1.2 \%$ of the respondents daily experience negative transfers from work to home. $33.8 \%$ have difficulties to fulfil their family responsibilities several times a week or several times a month because of the amount of time spent at work. For $14.2 \%$ of the survey participants this happened several times a year. Almost $50 \%$ state that they rarely or never had difficulties fulfiling their family responsibilities because of time-related job demands.

The negative transfer from home to work is less frequent compared to the transfer from work to home (Figure 12). The majority of the respondents $(71.4 \%)$ state that they rarely or never had difficulties concentrating at work because of family duties. For $16.1 \%$, this happened several times a week or several times a month. $12 \%$ of the survey participants had difficulties to work because of family engagements several times a year. Less than $1 \%$ report that they found it difficult to concentrate at work because of family responsibilities.

Figure 13 presents the ranked random coefficients () measuring the percentage of individuals in each country who positively evaluate the way their working time fits in with other family or social commitments and the estimated confidence intervals of these coefficients. The estimates show the deviation of a particular country from the group mean ("the average level of satisfaction"). If the confidence interval of a country coefficient does not include the group mean, marked with red line on the graph, with $5 \%$ risk of error it can be claimed that the level of satisfaction with working time in this country deviates significantly from the overall mean. In the present case, the estimates of the levels of satisfaction in most of countries significantly deviate from the group mean, showing that belonging to a particular country has a significant effect on the level of satisfaction with working time. This also reflects the importance of the socio-economic context in a particular country on the reconciliation of the time for professional and private life.

On the next step of the analysis, different factors of satisfaction with working time were explored using multilevel analysis (Table). The null model tests the influence of belonging to a particular country on individuals' satisfaction with working time. The model shows that there is a significant variation between the countries: $5 \%$ of the variance in the levels of satisfaction with working time is due to belonging to a particular country, i.e. to the prevailing regimes of working hours. This result is in line with findings from Anttila et al. who study the working time regimes in Europe and their specificity [12].
Model 1 shows that there is no significant difference by gender. When we control for age in Model 2, gender becomes statistically significant. The results from Model 2 reveal that women are more likely than men to report that they are satisfied with the reconciliation of their working time and family or social commitments. This result is in line with the research done by Clark [19] who found gender paradox in work satisfaction: women's jobs are worse than men's, yet women report higher levels of job satisfaction. Gender paradox in job satisfaction is confirmed also in a study conducted by Westover [20].

In Model 4, the influence of family characteristics (marital status, number of children and the presence of small children below the age of 6 years in the household) are added in the analysis. The results show that satisfaction with the balance of working time and private life significantly increases after the age of 40. Dobrow Riza, Ganzach and Liu [21] reveal an age paradox in work satisfaction: with the increase of age, workers became increasingly satisfied with their jobs when they gain work experience in different organisations, while with the increase of their employment in a given organisation, job satisfaction decreases.

Model 4 shows also that the respondents who are separated or divorced are less likely to report that they are satisfied with reconciliation of working time and family or social commitments. Bersoff and Crosby [22] also found significant relationship between job satisfaction and family status, with married parents expressing the highest job satisfaction and single adults having the lowest levels of satisfaction. The respondents who have children are more likely to report that they experience difficulties combining working time with the duties in private sphere compared to childless respondents (reference category). Respondents with small children below the age of 6 in the household are also less likely to report good reconciliation of working time and private life. Research done by Georgellis, Lange and Tabvuma [23] shows that female employees feel less satisfied with their jobs in the first years after childbirth. Georgellis, Lange and Tabvuma [23] also reveal that the effect is stronger for women, especially for the employees in the public sector. Gragnano, Simbula and Miglioretti [24] found that age, gender and parental status moderate the effect of work-family balance on job satisfaction.

Respondents who negatively evaluate their health status are less likely to be satisfied with working time (Model 5). Other studies also found negative association between job satisfaction and self-rated health $[25,26]$. The analysis shows that 
Two-level random intercept model for binary responses of the satisfaction with working hours

\begin{tabular}{|c|c|c|c|c|c|c|c|c|c|c|c|c|c|c|}
\hline & \multicolumn{2}{|c|}{ Null model } & \multicolumn{2}{|c|}{ Model 1} & \multicolumn{2}{|c|}{ Model 2} & \multicolumn{2}{|c|}{ Model 3} & \multicolumn{2}{|c|}{ Model 4} & \multicolumn{2}{|c|}{ Model 5} & \multicolumn{2}{|c|}{ Model 6} \\
\hline & Coef. & $P>z$ & Coef. & $P>z$ & Coef. & $P>z$ & Coef. & $P>z$ & Coef. & $P>z$ & Coef. & $P>z$ & Coef. & $P>z$ \\
\hline \multicolumn{15}{|l|}{ Gender } \\
\hline \multicolumn{15}{|l|}{ Male (ref.) } \\
\hline Female & & & 0.05 & & 0.06 & & 0.10 & $* *$ & 0.12 & $* * *$ & 0.11 & $* *$ & 0.11 & $* *$ \\
\hline \multicolumn{15}{|l|}{ Age } \\
\hline \multicolumn{15}{|l|}{$18-24$ (ref.) } \\
\hline $25-29$ & & & & & -0.12 & & -0.02 & & -0.01 & & -0.04 & & -0.04 & \\
\hline $30-34$ & & & & & -0.15 & & 0.07 & & 0.12 & & 0.07 & & 0.07 & \\
\hline $35-39$ & & & & & -0.26 & $* *$ & 0.03 & & 0.09 & & 0.04 & & 0.04 & \\
\hline $40-44$ & & & & & -0.12 & & 0.19 & * & 0.31 & $\star *$ & 0.25 & $* *$ & 0.24 & $* *$ \\
\hline $45-49$ & & & & & -0.06 & & 0.24 & $* *$ & 0.38 & $* * *$ & 0.33 & $* *$ & 0.33 & $* *$ \\
\hline $50+$ & & & & & 0.13 & & 0.42 & $* * *$ & 0.64 & $* * *$ & 0.56 & $* * *$ & 0.56 & $* * *$ \\
\hline \multicolumn{15}{|l|}{ Marital status } \\
\hline \multicolumn{15}{|l|}{ No partner (ref.) } \\
\hline Married & & & & & & & -0.01 & & -0.03 & & -0.04 & & -0.03 & \\
\hline Separated & & & & & & & -0.24 & $* *$ & -0.19 & * & -0.18 & * & -0.18 & * \\
\hline Widowed & & & & & & & 0.17 & & 0.22 & & 0.20 & & 0.21 & \\
\hline Divorced & & & & & & & -0.22 & $* *$ & -0.21 & $* *$ & -0.19 & $* *$ & -0.19 & $* *$ \\
\hline \multicolumn{15}{|l|}{ Number of children } \\
\hline \multicolumn{15}{|l|}{ No children (ref.) } \\
\hline 1 child & & & & & & & -0.38 & $* * *$ & -0.37 & $* * *$ & -0.34 & $* * *$ & -0.33 & $* * *$ \\
\hline 2 children & & & & & & & -0.43 & $* * *$ & -0.42 & $* * *$ & -0.39 & $* * *$ & -0.39 & $* * *$ \\
\hline $3+$ children & & & & & & & -0.44 & $* * *$ & -0.42 & $* * *$ & -0.36 & $* * *$ & -0.36 & $* * *$ \\
\hline \multicolumn{15}{|l|}{$\begin{array}{l}\text { Children below the } \\
\text { age of } 6 \text { in the } \mathrm{HH}\end{array}$} \\
\hline \multicolumn{15}{|l|}{ No (ref.) } \\
\hline Yes & & & & & & & -0.15 & $* *$ & -0.18 & $* *$ & -0.16 & $* *$ & -0.17 & $* *$ \\
\hline \multicolumn{15}{|l|}{ Self-rated health } \\
\hline \multicolumn{15}{|l|}{ Very good (ref.) } \\
\hline Good & & & & & & & & & -0.31 & $* * *$ & -0.30 & $* * *$ & -0.30 & $* * *$ \\
\hline Fair & & & & & & & & & -0.74 & $* * *$ & -0.70 & $* * *$ & -0.70 & $* * *$ \\
\hline $\mathrm{Bad}$ & & & & & & & & & -1.06 & $* * *$ & -1.00 & $* * *$ & -1.00 & $* * *$ \\
\hline Very bad & & & & & & & & & -0.85 & $* *$ & -0.82 & $* *$ & -0.82 & $* *$ \\
\hline Education & & & & & & & & & & & & & & \\
\hline $\begin{array}{l}\text { Below secondary } \\
\text { (ref.) }\end{array}$ & & & & & & & & & & & & & & \\
\hline Secondary & & & & & & & & & & & 0.02 & & 0.03 & \\
\hline Tertiary & & & & & & & & & & & 0.16 & $* *$ & 0.16 & $* *$ \\
\hline Income & & & & & & & & & & & & & & \\
\hline First quartile & & & & & & & & & & & -0.21 & ** & -0.21 & $* *$ \\
\hline Second quartile & & & & & & & & & & & -0.17 & $* *$ & -0.17 & $* *$ \\
\hline Third quartile & & & & & & & & & & & 0.04 & & 0.04 & \\
\hline Forth quartile (ref.) & & & & & & & & & & & & & & \\
\hline $\begin{array}{l}\text { Fifth (highest) } \\
\text { quartile }\end{array}$ & & & & & & & & & & & -0.02 & & -0.02 & \\
\hline Labour status & & & & & & & & & & & & & & \\
\hline $\begin{array}{l}\text { Employed/self- } \\
\text { employed/employer } \\
\text { (ref.) }\end{array}$ & & & & & & & & & & & & & & \\
\hline
\end{tabular}




\begin{tabular}{|c|c|c|c|c|c|c|c|c|c|c|c|c|c|c|}
\hline & \multicolumn{2}{|c|}{ Null model } & \multicolumn{2}{|c|}{ Model 1} & \multicolumn{2}{|c|}{ Model 2} & \multicolumn{2}{|c|}{\begin{tabular}{|l} 
Model 3 \\
\end{tabular}} & \multicolumn{2}{|c|}{ Model 4} & \multicolumn{2}{|c|}{ Model 5} & \multicolumn{2}{|c|}{ Model 6} \\
\hline & Coef. & $P>z$ & Coef. & $P>z$ & Coef. & $P>z$ & Coef. & $P>z$ & Coef. & $P>z$ & Coef. & $P>z$ & Coef. & $P>z$ \\
\hline $\begin{array}{l}\text { Employed (on } \\
\text { parental leave) }\end{array}$ & & & & & & & & & & & -0.15 & & -0.15 & \\
\hline $\begin{array}{l}\text { Employed (on other } \\
\text { leave - e.g. sick } \\
\text { leave, on vacation) }\end{array}$ & & & & & & & & & & & 0.13 & & 0.13 & \\
\hline $\begin{array}{l}\text { Retired and } \\
\text { working, incl. } \\
\text { self-employed }\end{array}$ & & & & & & & & & & & 0.48 & $* * *$ & 0.48 & ** \\
\hline $\log ($ GDP) & & & & & & & & & & & & & 0.48 & ** \\
\hline Constant & 1.27 & $* * *$ & 1.24 & $* * *$ & 1.29 & $* * *$ & 1.36 & $* * *$ & 1.57 & $* * *$ & 1.57 & $* * *$ & \begin{tabular}{|l|}
-0.12 \\
\end{tabular} & \\
\hline $\begin{array}{l}\text { Between group } \\
\text { variation }\end{array}$ & 0.17 & $* * *$ & 0.17 & $* * *$ & 0.16 & $* * *$ & 0.18 & $* * *$ & 0.19 & $* * *$ & 0.18 & $* * *$ & 0.14 & $* * *$ \\
\hline ICC & 0.05 & & 0.05 & & 0.05 & & 0.05 & & 0.05 & & 0.05 & & 0.04 & \\
\hline
\end{tabular}

Source: European Quality of Life Survey 2016, Eurofound.

Note: $(1){ }^{* * *} p \leq 0.01 ;{ }^{* *} 0.01<p \leq 0.05 ;{ }^{*} 0.05<p \leq 0.10$.

compared to low educated respondents (reference category), individuals with tertiary education are more likely to report that they are satisfied with their working time. Vila and García-Mora [27] found that the effect of educational level differs with regard to various aspects of job satisfaction. The difference depends on the type of job, actual job attributes and other workers' characteristics [27].

Model 5 reveals that compared to individuals with medium income (reference category), respondents from low income groups are less likely to report that their working time fits in well with family or social commitments. Results from a study conducted by Pouliakas and Theodosiou [28] uncover regional differences of the effect of income. Unlike Northern European countries, in Southern European countries low-paid employees are significantly less satisfied with their jobs compared to the high-paid employees. According to the results from Model 5 compared to the employed respondents (including self-employed and employers), the retired people who are still economically active are more likely to be satisfied with the reconciliation of working time and private life. Angrisani, Casanova and Meijer [29] found that older workers who experience high levels of work-life conflicts are significantly more likely to reduce their labour supply in order to achieve better work-life balance.

The last Model 6 includes a contextual variable measuring the socio-economic development through GDP per capita. The results reveal that socio-economic context has a significant influence on satisfaction with working time. GDP is positively associated with the levels of satisfaction with working time. Augner [30] points out that the national GDP is the single best indicator of job satisfaction. In the countries with high GDP, there are more opportunities for flexibilisation of work arrangements, better earning opportunities and more investments in work-life reconciliation policies aiming to increase wellbeing and overall satisfaction of working people.

\section{Conclusion}

The present study shed light on the influence of several factors on the satisfaction with working time in European countries. The study uncovers significant age and gender differences. Satisfaction with the reconciliation of working time and family or social commitments is higher for women compared to men. One of the explanations relates to the gender differences in employment. Women occupy job positions that usually have less time demands or allow for good reconciliation with family duties. Working time satisfaction increases after the age of 40 when individuals are in the middle of their professional career and the children have grown up. Having small children is associated with an increase of family responsibilities, which increase work-life conflict and dissatisfaction with working time, especially in countries where flexible forms of employment are rare, such as the Eastern European countries. On the individual level, lower socio-economic status is negatively associated with satisfaction with working time. Highly educated respondents have higher satisfaction compared to low educated individuals.

The present study reveals also that socio-economic context, i.e. a country's overall economic output and socio-economic development is a significant predictor of satisfaction with working 
time. In European countries with low GDP, satisfaction with working time decreases. This may be related to the standard working time regime that prevails in these countries and the rare practices of flexible work arrangements. In countries with high GDP, in which digitalisation of work and flexible forms of employment are more common, the satisfaction with time reconciliation of paid work and family duties is higher. This result from the present study reveals that the macroeconomic perspective needs to be taken into account in the context of the factors associated with job satisfaction and its dimensions.

The main conclusion is that there are strong differences among the European countries con- cerning work-life balance and its time dimension. Socio-economic differences between European countries reflect the increasing importance of diversification and individualisation in working arrangements in the recent period and have important consequences for employees' well-being, work-life balance and job satisfaction. The research findings on the factors associated with working time satisfaction in European societies in the times before the Covid-19 pandemic can serve as a comparison with the changing realities in the sphere of paid work in the recent times of a pandemic, featured by the fast spread-out of flexible forms of employment and ICT based telework.

\section{References}

1. Cijan, A., Jenič, L., Lamovšek, A. \& Stemberger, J. (2019). How digitalization changes the workplace. Dynamic Relationships Management Journal, 8(1), 3-12. DOI: 10.17708/DRMJ.2019.v08n01a01.

2. MacDonald, W. (2011). The Impact of Job Demands and Workload on Stress and Fatigue. Australian Psychologist, 38(2), 102-117. DOI: 10.1080/00050060310001707107.

3. Tulgan, B. (1996). Managing Generation X. Oxford: Capstone, 228.

4. Goode, W. J. (1960). A Theory of Role Strain. American Sociological Review, 25(4), 483-496. DOI: 10.2307/2092933.

5. Clark, S. C. (2000). Work/Family Border Theory: A New Theory of Work/Life Balance. Human Relations, 53(6), 747770. DOI: $10.1177 / 0018726700536001$.

6. Guest, D. 2002. Perspectives on the Study of Work-Life Balance. Social Science Information, 41, 255-279. DOI: 10.1177/0539018402041002005.

7. O’Driscoll, M. (1996). The Interface between Job and Off-Job Roles: Enhancement and Conflict. International Review of Industrial and Organizational Psychology, 11, 279-306. DOI: 10.1002/9780470745267.

8. Greenhaus, J. H. \& Allen, T. D. (2011). Work-Family Balance: A Review and Extension of the Literature. In: J. C. Quick, L. E. Tetrick (Eds.), Handbook of Occupational Health Psychology (pp. 165-183). American Psychological Association, Washington, D. C.

9. Carlson, D. S., Grzywacz, J. G. \& Zivnuska, S. (2009). Is Work-Family Balance More than Conflict and Enrichment? Human Relations, 62(10), 1459-1486. DOI: 10.1177/0018726709336500.

10. Greenhaus, J. H. \& Powell, G. N. (2006). When Work and Family are Allies: A Theory of Work-Family Enrichment. Academy of Management Review, 31(1), 72-92. DOI:10.5465/AMR.2006.19379625.

11. Marks, S. R. \& MacDermid, S. M. (1996). Multiple Roles and the Self: A Theory of Role Balance. Journal of Marriage and Family, 58(2), 417-432. DOI: 10.2307/353506.

12. Anttila, T., Oinas, T., Tammelin, M. \& Nätti, J. (2015). Working-Time Regimes and Work-Life Balance in Europe. European Sociological Review, 31(6), 713-724. DOI: 10.1093/esr/jcv070.

13. Shagvaliyeva, S. \& Yazdanifard, R. (2014). Impact of Flexible Working Hours on Work-Life Balance. American Journal of Industrial and Business Management, 4(1), 20-23. DOI: 10.4236/ajibm.2014.41004.

14. Campbell, I. \& van Wanrooy, B. (2013). Long working hours and working-time preferences: Between desirability and feasibility. Human Relations, 66(8), 1131-1155. DOI: 0.1177/0018726713478641.

15. Tijdens, K. G. (2003). Employees' and Employers' Preferences for Working Time Reduction and Working Time Differentiation: A Study of the 36-Hour Working Week in the Dutch Banking Sector. Acta Sociologica, 46(1), 69-82. DOI: $10.1177 / 0001699303046001005$.

16. Messenger, J. (Ed.). (2004). Working Time and Workers' Preferences in Industrialized Countries. London and New York: Routledge, 256.

17. Dimitrova, E. K. (2019). Social Differences in the Attitudes Towards the Balance of Time for Paid Work and Private Life in European Perspective. In: Sotsialno-ekonomicheskie i demograficheskie aspekty realizatsii natsionalnykh proektov $v$ regione: sbornik statey X Uralskogo demograficheskogo foruma. Tom I [Socio-economic and demographic aspects of the implementation of national projects in the region: a collection of articles of the X Ural Demographic Forum. Volume 1] (pp. 118-124). Ekaterinburg: Institute of Economics UB RAS.

18. Zedeck, S. \& Mosier, K. L. (1990). Work in the Family and Employing Organization. American Psychologist, 45(2), 240-251 DOI: 10.1037/0003-066X.45.2.240.

19. Clark, A. (1997). Job satisfaction and gender: Why are women so happy at work? Labour Economics, 4(4), $341-372$. DOI: 10.1016/S0927-5371(97)00010-9. 
20. Westover, J. H. (2012). The job satisfaction-gender paradox revisited: A cross-national look at gender differences in job satisfaction, 1989-2005. Journal of Global Responsibility, 3(2), 263-277. DOI: 10.1108/20412561211260557.

21. Dobrow Riza, S., Ganzach, Y. \& Liu, Y. (2016). Time and job satisfaction: a longitudinal study of the differential roles of age and tenure. Journal of Management, 44(7), 2558-2579. DOI: 10.1177/0149206315624962.

22. Bersoff, D. \& Crosby, F. (1984). Job Satisfaction and Family Status. Personality and Social Psychology Bulletin, 10(1), 79-83. DOI; 10.1177/0146167284101008.

23. Georgellis, Y., Lange, Th. \& Tabvuma, V. (2012). The impact of life events on job satisfaction. Journal of Vocational Behavior, 80(2), 464-473. DOI: 10.1016/j.jvb.2011.12.005.

24. Gragnano, A., Simbula, S. \& Miglioretti, M. (2020). Work-Life Balance: Weighing the Importance of Work-Family and Work-Health Balance. International Journal of Environmental Research and Public Health, 17(3), 907. DOI: 10.3390/ ijerph17030907.

25. Faragher, E., Cass, M. \& Cooper, C. (2005). The relationship between job satisfaction and health: a meta-analysis. Occupational and Environmental Medicine, 62, 105-112. DOI: 10.1136/oem.2002.006734.

26. Fischer, J. \& Sousa-Poza, A. (2007). Does Job Satisfaction Improve the Health of Workers? New Evidence Using Panel Data and Objective Measures of Health. IZA DP No. 3256. Retrieved from: http://ftp.iza.org/dp3256.pdf (Date of access: 10.05.2020)

27. Vila, L. E. \& García-Mora, B. (2005). Education and the Determinants of Job Satisfaction. Education Economics, 13(4), 409-425. DOI: 10.1080/09645290500251730.

28. Pouliakas, K. \& Theodosiou, I. (2010). Differences in the job satisfaction of high-paid and low-paid workers across Europe. International Labour Review, 149(1), 1-29. DOI: 10.1111/j.1564-913X.2010.00073.x.

29. Angrisani, M., Casanova, M. \& Meijer, E. (2020). Work-Life Balance and Labor Force Attachment at Older Ages. Journal of Labor Research, 41(1-2), 14. DOI: 10.1007/s12122-020-09301-8.

30. Augner, C. (2015). Job satisfaction in the European Union: the role of macroeconomic, personal, and job-related factors. Journal of occupational and environmental medicine, 57(3), 241-245. DOI: 10.1097/JOM.0000000000000398.

\section{About the author}

Elitsa Kuzdova Dimitrova - PhD, Associate Professor, Institute for Population and Human Studies - Bulgarian Academy of Sciences; https://orcid.org/0000-0002-5697-220X (6, Acad. Georgi Bonchev St., Sofia, 1113, Bulgaria; e-mail: elitsa_kdimitrova@yahoo.com).

\section{Информация об авторе}

Димитрова Элица Куздова - $\mathrm{PhD}$, доцент, Институт народонаселения и гуманитарных исследований Болгарской академии наук; https://orcid.org/0000-0002-5697-220X (Болгария, 1113, г. София, ул. акад. Георги Бончева, 6; e-mail: elitsa_kdimitrova@yahoo.com).

Дата поступления рукописи: 06.02.2020. Прошла рецензирование: 12.04.2020. Принято решение о публикации: 24.09.2021. Received: 06 Feb 2020. Reviewed: 12 Apr 2020. Accepted: 24 Sep 2021. 